Case Report

\title{
Modified cervicofacial flap for temporal region reconstruction post basal cell carcinoma excision
}

\author{
Lorensia Fitra Dwita, Al Hafiz \\ *Department of Otorhinolaryngology - Head and Neck Surgery \\ Faculty of Medicine Andalas University/Dr. M. Djamil General Hospital, \\ Padang
}

\begin{abstract}
Background: Cervicofacial flap is considered to be the main choice for reconstruction of large defect in skin malignancies at head and neck such as basal cell carcinoma. Cervicofacial flap has a high successfull rate, due to the excellent vascularization, also the suitable matching in colour, thickness and texture. Purpose: To find out the result of reconstruction with modified cervicofacial flap after wide excision of basal cell carcinoma. Case report: A case of a 54-year-old-woman with basal cell carcinoma of the skin at right temporal region. Reconstruction of the temporal area was performed using a modified cervicofacial flap and followed by adjuvant radiotherapy, which resulted in a good outcome. Clinical Question: Is modified cervicofacial flap, the appropriate technique for defect reconstruction of post excision basal cell carcinoma at temporal region? Review method: Evidence based literature study of the procedure and outcome after reconstruction with modified cervicofacial flap through Cochrane library, Pubmed Medline, and hand searching. Result: Cervicofacial flap has a good vascularization, gave a blending colour, and almost similar healthy skin texture with its surrounding. Conclusion: Cervicofacial flap is the best technique for large defect in head and neck area, particularly in the face. Cervicofacial flap is also used for covering the cutaneous defect at facial and cheek region due to malignancy, particularly for basal cell carcinoma. It produces a good outcome.
\end{abstract}

Keywords: cervicofacial flap, modified, basal cell carcinoma, defect reconstruction

\begin{abstract}
ABSTRAK
Latar belakang: Flap servikofasial dianggap merupakan pilihan utama untuk rekonstruksi defek yang luas pada keganasan kulit pada area kepala dan leher, seperti karsinoma sel basal. Flap servikofasial memiliki tingkat keberhasilan yang cukup tingg, karena jenis flap ini memiliki vaskularisasi yang baik serta memberikan keserasian warna, ketebalan dan tekstur yang sesuai. Tujuan: Mengetahui keberhasilan rekonstruksi dengan teknikflap servikofasial modifikasi pasca eksisi karsinoma sel basal. Laporan kasus: Seorang wanita berusia 54 tahun dengan diagnosis karsinoma sel basal kulit regio temporalis dekstra. Pada pasien telah dilakukan rekonstruksi daerah temporal dengan teknik flap servikofasialis modifikasi serta dilanjutkan dengan radioterapi adjuvan. Penatalaksanaan tersebut memberikan hasil yang memuaskan. Pertanyaan Klinis: Apakah teknik servikofasial flap modifikasi merupakan teknik yang tepat untuk menutup defek pasca eksisi karsinoma sel basal regio temporal? Telaah literatur: Berbasis bukti mengenai teknik dan hasil dari rekonstruksi dengan flap servikofasialis modifikasi melalui database Cochrane library, Pubmed Medline, dan pencarian manual. Hasil: Flap servikofasial memberikan vaskularisasi yang baik, warna yang sesuai dan mendekati tekstur kulit sehat sekitarnya. Kesimpulan: Flap servikofasial merupakan teknik flap terbaik untuk menutupi defek yang luas pada kepala dan leher, terutama pada area wajah. Flap servikofasial juga digunakan untuk menutup defek pada kulit wajah dan pipi akibat keganasan, terutama pada karsinoma sel basal, dan memberikan hasil yang baik.
\end{abstract}

Kata kunci: flap servikofasialis, modifikasi, karsinoma sel basal, rekonstruksi defek 
Correspondence address: Lorensia Fitra Dwita. Department of Otorhinolaryngology - Head and Neck Surgery Faculty of Medicine Andalas University/ Dr. M. Djamil General Hospital, Padang. Email: lorensiadwita.tan@yahoo.com.

\section{INTRODUCTION}

Cervicofacial flap is one of technique choices for large defect reconstruction. Cervicofacial flap technique is considered to be the main choice for reconstruction of large defect particularly in head and neck area. ${ }^{1,2}$ Compound cervicofacial and cervicothoracic rotation flaps are highly versatile flaps that may be applied to a variety of the defects of the cheek, orbit, periauricular region, and the neck. These rotation advancement flaps should be a staple of the head and neck surgeon's reconstructive armamentarium. ${ }^{3}$ Esser introduced this technique for the first time in 1918 for cheek reconstruction. ${ }^{3,4}$

The cervicofacial rotation advancement (CRAF) is a random-pattern flap that provides an excellent match for cheek reconstruction. The name cervicofacial flap was first used by Kaplan in 1978 in a report of the versatility of this flap for the coverage of defects following the removal of cancer of the head and neck. ${ }^{5}$

Cervicofacial flaps had often been used to fit defects of the face, cheek, parotid region, periorbital region, auricle and neck particularly in certain high risk patients such as the elderly and those with systemic diseases. Cervicofacial flap technique could be modified according to the defect's width.

Cervicofacial flap has many advantages than other techniques, among others are technically simple, reliable with low failure rate, single team approach, shorter anesthetic and surgical times, can be performed under local anesthesia, no postoperative ICU monitoring required, single-stage procedure, few perioperative complications and morbidity, and versatile with multiple applications. This technique receives vascularization from 2 directions (cervical and facial), therefore the vascularization supply is adequate for the large defect, gives good skin color, thickness and texture match between cervical and facial skin. ${ }^{7,8}$

The purpose of presenting this case was to report the result of reconstruction with modified cervicofacial flap after wide excision of basal cell carcinoma (BCC), performed in Department of Otorhinolaryngology - Head and Neck Surgery of Dr. M. Djamil General Hospital, Padang.

\section{CASE REPORT}

A 54 years old female patient was referred to Facial Plastic and Reconstructive Surgery Clinic of the Department of Otorhinolaryngology - Head and Neck Surgery Dr. M. Djamil General Hospital, Padang on July 22 $2^{\text {nd }}, 2019$ with main complaint of open wound on the right ear that could bleed easily. Excision biopsy and reconstruction was already performed by an Otorhinolaryngologist at Solok Regional Hospital two years previously, and was diagnosed as basal cell carcinoma. Surgery had been performed twice. There was bleeding with purulent discharge from the right ear, on and off since the last 6 months, and weight loss $>10 \mathrm{~kg}$ in one year. The patient was a farmer.

Upon physical examination, patient's general condition was good, compos mentis, and the vital signs were in normal range. Ear Nose and Throat (ENT) examination showed no abnormality in the nose, throat and left ear. At the outer side of the right ear - could be seen helix and tragus destruction and pinna avulsion (Picture 1b). The right external ear canal was difficult to be assessed. At right temporal region an open, easily bleed ulcerative wound with necrotic tissue sized 


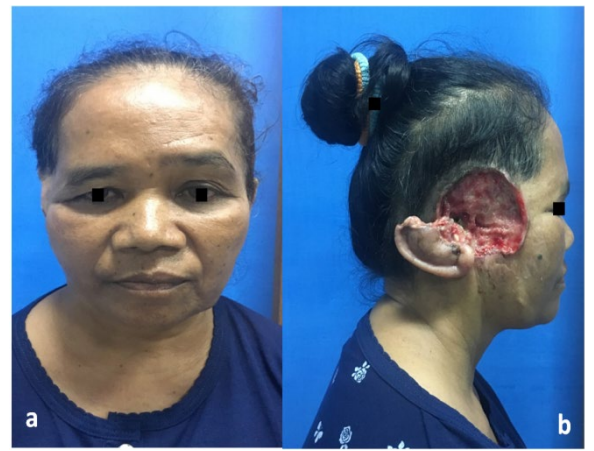

Figure 1. (a) Patient's front view (b) Helix and tragus destruction

90x80x10 mm and clear margin could be seen. No lymph nodes enlargement was found in the neck area.

From the anamnesis and physical examination, the definitive diagnosis was basal cell carcinoma of the skin at right temporal region. The plan was to perform debridement and temporal reconstruction with cervicofacial flap in general anesthesia. The risks and surgery procedures were explained to patient and her family, and they approved by signing the informed consent. The preoperative laboratory result, internal medicine and anesthetic examinations were normal.

Surgery was performed on July $31^{\text {st }}, 2019$. Patient was in supine position on the operation table under general anesthesia. Aseptic and antiseptic measures were executed, followed by putting incision marker and flap border 1 $\mathrm{cm}$ beyond tumor's outside line in surgery field. Infiltration of epinephrine 1:100.000 was given in surgery field. The open wound was wholly evaluated, and undermining was performed around the wound. All tumor and granulation tissue along the wound's line were excised and curretaged. Tumor mass was sent to the Anatomical Pathology Department for frozen section examination after being marked at 4 borders. The result was basal cell carcinoma with free border.

The skin of area was marked, and incision was made along the marked border, followed by undermining the skin piece until beneath the fascia, posteriorly starting from the preauricular crease. Then the skin and fascia was lifted to cover the ear and temporalis defect. The external ear canal was beyond recognition, and the facial nerve was also could not be identified. Next, an incision was carried out from the lateral side of trapezius, extended until the inferior border of 1/3 upper thoracal area, as wide as the open defect of the right neck. The skin and the associated fascia was then released and rotated to become the flap. This flap covered all the remnant of open wound in the upper right neck, and then the flap was secured with interior and exterior stitches. An incision was also made into the external ear canal, and covered with sofratulle. Small drains were then installed in several places. Wound stitches were covered with sofratulle and bandages. Patient received Ketorolac in ringer lactat intra vena fluid drips (IVFD) every 8 hours, 2x1gr Ceftriaxone injection, and Dexamethasone $3 \times 5 \mathrm{mg}$.

On the $3^{\text {rd }}$ day postoperative, the bandage was removed, the antibiotic gauze was replaced, and the empty drain was taken out. It could be seen a hyperemic, blackish stitched wound around the flap. Sensoric examination around the wound showed normal condition. Then the wound was covered again with a new sofratulle layered gauze. The antibiotic therapy was continued.

On the $5^{\text {th }}$ day postoperative, the wound stitches were hyperemic. Crust and hyperemic skin was seen in flap border. The pain in neck and right shoulder region was minimal. No limitation of head movement. Sensoric 
examination around the wound showed normal condition. The wound was again covered with sofratulle layered gauze. Patient was discharged from the hospital, with medication of Clindamycin $3 \times 300 \mathrm{mg}$ and Ibuprophen $3 \times 400 \mathrm{mg}$, and was advised to do follow up after one week.

On August 14 ${ }^{\text {th }}, 2019$, two weeks postoperative, the patient came to ENT-HNS polyclinic. Patient complained that surgery wound was still wet, hyperemic and persisting pain. After cutting out the stitches, the wound was cleansed and amnion was installed. Sensoric examination around the wound was in normal condition. Chloramphenicol ointment was given to patient. Patient was referred to radiotherapy for further treatment.

On December $3^{\text {rd }}, 2019$, six months after surgery, the patient came to the ENT-HNS polyclinic. Patient had received 35 times radiation in a private clinic.

The wound was good, no abnormality seen, no pain, no purulent discharge from the wound, and no limitation of head and neck movement (Picture 2). Patient was diagnosed with post reconstruction with modified cervicofacial flap at right temporalis region, based on indication of basal cell carcinoma of right temporalis region.

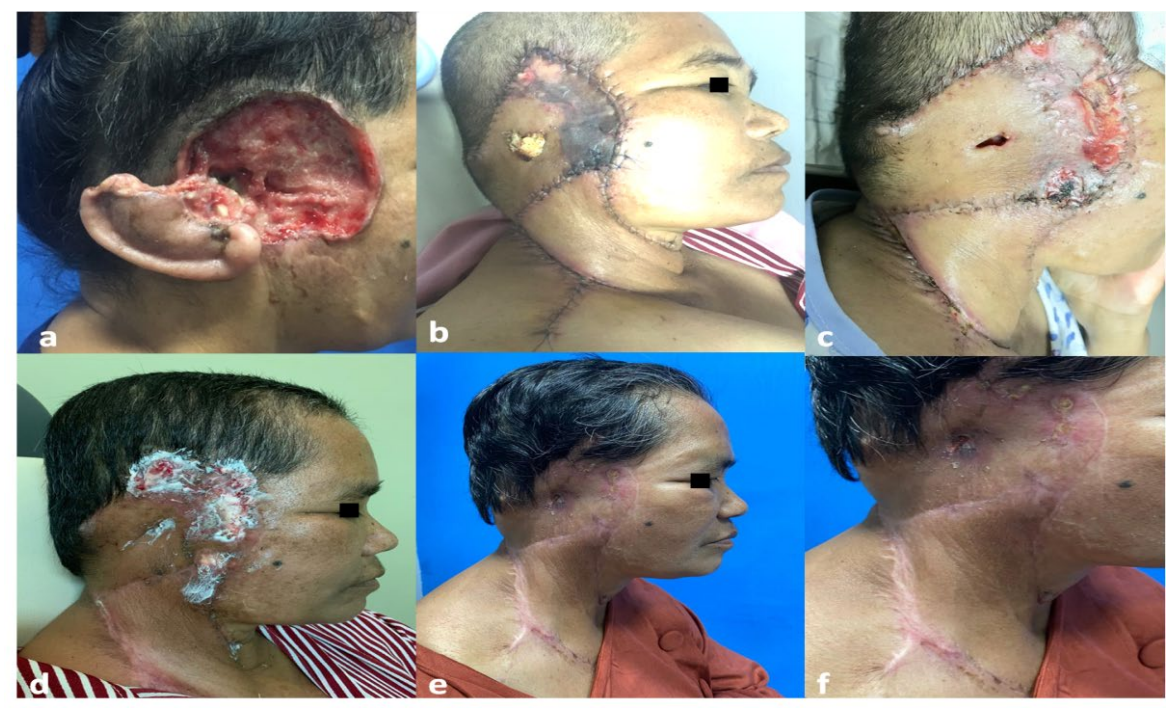

Figure 2. (a) Pre-op picture, (b) 5 days postoperative, (c) 2 weeks postoperative, (d) Pre radiotherapy, (e,f) 6 months postoperative

\section{CLINICAL QUESTION}

Is modified cervicofacial flap technique, the appropriate technique for defect reconstruction of post excision basal cell carcinoma at temporal region?

\section{REVIEW METHOD}

The literature study searching procedure used keywords "cervicoflap" AND "modified cervicoflap" AND "modified approach to cervicofacial technique" through Cochrane library, Pubmed Medline, and hand searching.
The result of literature searching was selected using inclusion criteria as follows: 1) patient with wide defect of temporalis region, and the reconstruction was performed with cervicofacial flap, 2) patient with wide defect of temporalis region, and the reconstruction was performed with modified cervicofacial flap technique. The exclusion criteria were patients with temporal defect accompanied with comorbidity (smoker, exposure of radiotherapy and the presence of metabolic disorder). Critical evaluation was executed on 2 literatures. 


\section{RESULT}

A research was conducted by Nakade $^{6}$ in India (2012-2015) on 12 patients with various cheek defects reconstructed using cervicofacial flap. He concluded that cervicofacial flap was a simple technique, producing a good cosmetic result with minimal scar and presenting a satisfying color match and skin texture.

Another retrospective research was done by Bokhari ${ }^{7}$ in the United States of America on 16 patients with skin malignancy in the head and neck region, particularly in cheek and external ear area (5 patients underwent auriculectomy). He concluded that reconstruction using cervicofacial flap and its modification was a fast and simple technique, and presented a satisfying esthetically result for a wide cutaneous defect involving cheek and external ear region.

\section{DISCUSSION}

A reconstruction using modified cervicofacial flap, post wide excision of basal cell carcinoma at right temporalis region had been performed. Basal cell carcinoma (BCC) had - the highest incidence (80\%) in head and neck region, and in particular of auricule was $6 \%{ }^{9}$

The gold standard of BCC management is complete excision of tumor mass with or without adjuvant radiotherapy. This procedure is compliant with NCCN (National Comprehensive Cancer Network),${ }^{10}$ year 2016 on the BCC management. The BCC is divided into high risk and low risk. According to the $\mathrm{NCCN}$, this reported case was categorized as high risk based on tumor location in facial area with wound measurement $\geq 12 \mathrm{~mm}$, so that it should be treated with surgical excision and radiation.

Liu, ${ }^{11}$ reported that the cervicofacial flap was first applied in 1978 to cover the defect of cancer complete excision in head and neck region. This technique had proven to give a satisfying result functionally and esthetically. Cervicofacial flap provides the simplest technique and at the same time also protecting vital structures such as facial nerve, mandibula and carotid artery.

Hamama, ${ }^{5}$ also declared similar statement that cervicofacial flap was the right choice in the treatment of patients with cheek cancer where comorbid conditions preclude lengthy operations, since a single incision was adequate for excision, neck dissection and reconstruction of the defect. Genden, ${ }^{12}$ reported that cervicofacial flap was one of the best techniques to close cutaneous defect in the face and cheek area, such as in BCC case.

In our case, the patient with BCC of the skin at right temporal region, was referred to the ENT-HNS Department, dr.M.Djamil General Hospital, Padang. Beforehand, an excisional biopsy had already been performed at a regional hospital 2 years previously, but the patient's condition had worsened. As the management procedure, the patient underwent a complete excision of the tumor mass and modified cervicofacial flap for reconstruction of the defect, followed by adjuvant radiation therapy.

Bokhari, ${ }^{7}$ stated that cervicofacial flap was the right choice for patient with malignancy at cheek skin and external ear regions. Nevertheless, for a wide defect, this flap often needs further incision or a modification up to thoracal region or even reaching up to deltopectoral area. But the defect result had become very tense, due to a very wide undermining. Bokhari, ${ }^{7}$ performed a modified anterior cervicofacial flap technique on a wide defect in the cheek, which minimized undermining to provide a tension-free closure of the defect. This technique gave cosmetically good result with minimum scar.

In our case report, the patient had an open defect in right temporalis region and 
destruction of external ear. This modified cervicofacial flap technique with additional incision of thoracal region, which did not reach the deltopectoral area, had given a satisfying result and no tension in the defect wound.

Van Onna, ${ }^{13}$ stated that the post cervicofacial flap reconstruction complications, was divided into early complication ( 8 weeks after surgery) and late complication (one year after surgery). In his retrospective study on 54 patients, 8 patients had early complication in the form of hematoma (4\%), necrosis, infection, and dog-ear, while late complication happened to 17 patients with sensory neuropathy, and 12 patients with discoloration of flap area. Based on his study, Van Onna, ${ }^{13}$ advised that follow-up should be carried out until minimally 1 year post reconstruction with flap.

Rhodes, ${ }^{1}$ disclosed that one of major disadvantage of the cervicofacial flap was the susceptibility of the distal edge to necrosis and dehiscence due to random blood supply and amount of subcutaneous dissection required, especially for larger defects. Patients who had a history of radiation and use of tobacco were at greater risk for flap compromise. The facial nerve was theoretically at risk during surgery. Caution during subcutaneous dissection was important during the procedure to avoid facial nerve palsy. Therefore, it was advisable to do subcutaneous dissection immediately superficial to the superficial musculoaponeurotic systems (SMAS), preventing the facial nerve from injury.

In our case, 2 weeks after the surgery, the patient had necrosis in the distal edge flap. Six months postoperative, and after radiotherapy was given, the surgery wound was normal, good vascularization, similar color and texture with the surrounding tissue, and no contracture (tension).

Sharma ${ }^{4}$ found out from his study that cervicofacial flap and cervicothoracic rotation flaps technique are highly versatile flaps that could be applied to a variety of the defects of the cheek, orbit, periauricular region and the neck, and gave good vascularization and satisfying esthetic for the face area. Hamama, ${ }^{5}$ also stated that rotation-advancement of cervicofacial flap gave good colorization and similar thickness and texture with the surrounding tissue.

Cervicofacial flap technique could be used to reconstruct a wide defect in the head and neck regions, especially in the face area. The incision could be adjusted according to the width and size of the defect. The modified cervicofacial flap technique for reconstructing large defect post excision $\mathrm{BCC}$ at temporal region provided a very satisfying result

\section{REFERENCE}

1. Rhodes R, Moreau A, Romano E, Cannon T. The cervicofacial flap. Oper Tech Otolaryngol Head Neck Surg. 2019; 30(2):145-50.

2. Cho YY. Soft Tissue Reconstruction: Face and Neck. In: Head and Neck Reconstruction. First. Elsevier; 2009. p.5-10.

3. Moore BA, Wine T, Netterville JL. Wax MK (Ed). Cervicofacial and cervicothoracic rotation flaps in head and neck reconstruction. Wiley Interscience 27. 2005: 1092-101.

4. Sharma SP, Nigam A. Case report. Modified cervicofacial flap for large cheek defect reconstruction under local anesthesia. Hindawi. 2019; 1: 1-5.

5. Hamama J, Khalfi L, Achbouk K, Fiqhi K, El Khatib K. Cervicofacial rotation and advancement flap in cheek reconstruction. Int J Med and Surg. 2018: 1-4.

6. Nakade DV, Mehta J, Zade M, Shahane P. Cervicofacial flap revisited. Int J Res Med Sci. 2016; 4(11): 4669-74.

7. Bokhari WA, Wang SJ. Modified approach to the cervicofacial rotation flap in head and neck reconstruction. Int $J$ Open Otorhinolaryngol. 2011; 5: 18-24.

8. Manana W, Fagan J. Cervicofacial flaps in head and neck reconstruction. Open Access 
Atlas of Otolaryngology Head \& Neck Operative Surgery. 1979:1-3.

9. Lohuis PJFM, Joshi A, Borggreven PA, Vermeeren L, Zupan-Kajcovski B, AlMamgani A, et al. Aggressive basal cell carcinoma of the head and neck: challenges in surgical management. Eur Arch Otorhinolaryngol. 2016: 1-9.

10. Engh A, Hoffmann KG. NCCN, Guidelines Basal Cell Skin Cancer. 2016: 7-9.

11. LiuF, XuZ, LiP, et al. The versatile application of cervicofacial and cervicothoracic rotation flaps in head and neck surgery. World J Surg Oncol. 2011; 9(135): 1-7.

12. Genden EK. Cheek and neck reconstruction. In: Weber SM, Wax MK, eds. Reconstruction of the head and neck. $1^{\text {st }}$ ed. Stuttgart: Thieme; 2012: 75-9.

13. Van Onna MA, Haj M, Smit JM, Hoogbergen MM. Long-term outcome of the cheek advancement flap, a report of 41 cases. J Plastic Surg Hand Surg. 2016; 50(6): 354-8. 